\title{
THE TERRITORIAL CONTEXTS OF INDUSTRY 4.0 IN HUNGARY, THE PRESENT AND FUTURE CHALLENGES AND EXPECTATIONS OF THE DIGITAL ECOSYSTEM
}

\author{
Gábor NICK $^{\mathrm{a}}$, Tamás VÁRGEDŐ ${ }^{\mathrm{b}}$, Csongor NAGY $^{\mathrm{c}}$, Ádám SZALLER ${ }^{\mathrm{d}}$ \\ a Institute for Computer Science and Control (SZTAKI), Hungarian Academy of Sciences (MTA), \\ Budapest, Hungary.E-mail: nick.gabor@sztaki.mta.hu \\ ${ }^{\mathrm{b}}$ Industry4.0 National Technological Platform, Budapest, Hungary, tamas.vargedo@sztaki.mta.hu \\ ${ }^{\mathrm{c}}$ Earth Sciences PhD Program, University of Debrecen, Debrecen, Hungary, csongormagnus@gmail.com \\ ${ }^{\mathrm{d}}$ Institute for Computer Science and Control (SZTAKI), Hungarian Academy of Sciences (MTA), \\ Budapest, Hungary; Department of Manufacturing Science and Engineering, Budapest University of \\ Technology and Economics, Budapest, Hungary, szaller.adam@sztaki.mta.hu
}

Cite this article: Nick, G., Várgedő, T., Nagy, C., Szaller, Á. (2019). The territorial contexts of Industry 4.0 in Hungary, the present and future challenges and expectations of the digital ecosystem. Deturope. 11(3), 29-58.

\begin{abstract}
In the article we present our ecosystem based approach of industrial digitalization in Hungary, and provide empirical evidence that Industry 4.0 doesn't create a uniform platform for the expectations of the actors of the Hungarian industrial digitization ecosystem in respect to the expected priorities of macro level industry policy; and regarding the implementation of the innovations there are differences between the actors in dependence of their geographical location. In the empirical part of the article we rely on the survey of the Industry 4.0 National Technology Platform and demonstrate its conclusions. We also introduce the dualistic structure of industry in Hungary by creating groups of counties on the basis of macroeconomic indicators. We highlight the regional differences using our own Industry 4.0 readiness classification system. Based on our results it was confirmed that the digital transformation of the industry can be achieved only by applying differentiated, region specific and ecosystem based tools.
\end{abstract}

Keywords: Industry 4.0, I4.0, Digital ecosystem, Territorial challenges

\section{INTRODUCTION}

The accelerating integration processes of the info-communication technologies and the cyberphysical production and logistic systems have generated fundamental changes in the economy which are denoted today shortly as the Industry 4.0 (Monostori et al., 2016; Schuh et al., 2017; Kagermann, Wahlster, \& Helbring, 2013). The notion of Industry 4.0 has become part of public knowledge, although the exact interpretation of its definition is still subject to frequent discussions. There is a unanimous consensus in one issue only, namely with respect to the impacts of Industry 4.0 on competitiveness both at the micro and macro levels (Kagermann et al., 2013; Szalavetz, 2016a, 2016b). The new innovations in industrial digitalization and consequently, the changes in the business paradigm induce substantial changes in the internal operation and business model of industrial companies and, in parallel with this, their external relationships as well and affect also to a great extent the expectations towards their economic 
environment (Spath et al., 2013; Monostori et al., 2016). This progress stipulates changes in the structure of value chains, that can (and does indeed) affect the investment and relocation strategies of companies (Szalavetz, 2016a; Porter \& Heppelmann, 2014). In addition to the technical readiness of the enterprises, (sharing) knowledge and research collaboration will be the key issues in the future. In order to survive, industrial players need to increase their productivity, offer innovative services with higher added value, and create personalized products at mass prices.

The cooperation of local actors in the field of innovation is expected to lead to the development of the regions - as territorial development is also an important tool to improve competitiveness (Lengyel, 2010, 2016; Rechnitzer, 1998). In the coming period, the state institutional system (including research and education) will play a prominent role which is already proved by the prevalent economic development programmes and industrial policy of several countries. Other actors of the envisioned new ecosystem are social and professional organizations, and humans who are always to stay in the focal point.

The development path of the Hungarian economy is approaching a turning point. Like most East-Central European countries with a dualistic economic structure similar to that in Hungary (driven by powerful, technologically advanced foreign companies, in contrast to a number of small and medium sized local actors usually in the role of suppliers), and who are in the reindustrializing process, the growth of the past period in Hungary was largely based on exportoriented production primarily on the ground of available high-value-for-money workforce. Surprisingly, Hungary is one of the most industrialized countries in Europe with industry's share of GDP at $23.5 \%$ in 2014, whose economic performance is highly dependent on car manufacturing and its related industries (Roland Berger, 2016a; Pongrácz \& Nick, 2017; NGM, 2016). At the government level, and in line with the European Union's reindustrialization strategy, the Hungarian government intends to foster the digitisation of industry. The Irinyi Plan is a complex toolkit that defines the directions of the targeted innovative industrial development. As a declared main objective, industry's share in the gross domestic product is to rise to $30 \%$ by 2020 .

Established in 2016, the Hungarian Industry 4.0 National Technology Platform (2016, NTP) launched its first questionnaire project that explores the Hungarian Industry 4.0 ecosystem, i.e. the technological and business maturity of individual companies from the digitization point of view, and provides also an insight into the current trends in the relevant macroeconomic developments. The description of the questionnaire can be found in Nick et al. (2019).

The purpose of this paper is to highlight from the territorial dependence perspective the results of the empirical research on the sample of Hungarian companies potentially involved in Industry 4.0, and place them into a broader economic context. The main hypothesis of the study 
is that the potential regional differences in the Industry 4.0 related issues will show perceptible connection with the geographic consequences of the dualistic structure of the Hungarian industry. Therefore, the information received from the respondents was analysed from the aspects of:

- company size, ownership, industry and their international economic embeddedness;

- the evaluation of their status in terms of technical development, innovative potential and human resources' competencies;

- the perception of the current economic and institutional environment considering the key Industry 4.0 issues and addressing the respondents' expectations, too.

This will also provide the possibility to examine the role and state of readiness of SMEs. On the one hand, it is a highly important point because the conditions of competition are going to change for suppliers and providers of services too, and on the other hand, SMEs have a significant influence on regional competitiveness as well (Kovács, Lux, \& Páger, 2017).

\section{THEORETICAL BACKGROUND}

\section{Territorial competitiveness}

The concept of cyberspace is becoming more and more common, but this doesn't neutralise the relevance of the geographic location where a given economic actor performs its activity. Therefore, we consider it important to identify and reveal the factors that affect the relationship between territorial criteria and Industry 4.0 companies.

As people in everyday life, countries, regions and cities are constantly competing with each other for better resources. One aim could be to increase the number of more skilled workers as they are able to create better and more products - but it is also important to acquire more financial resources (Porter, 1990).

In economic terms, the competition is defined as the activity of two or more players to gain advantage over each other, observing certain rules (Chikán, 2008). At the company level, it means to win a better position in the market place; for countries and regions the competition can be considered as to reach a better situation at a regional level. In OECD terms, competitiveness is the ability of companies, industries, regions and supranational regions to generate relatively high income and attain a relatively high level of employment on a sustainable basis, while being exposed to international competition permanently. (CEC, 1996; OECD, 1997, 1998).

The government's ambition for the $21^{\text {st }}$ century Europe is the conceptual, strategic management of areas and the elimination of inequalities between the developed and the 
underdeveloped areas. This is an interesting counterpoint to competition, given that it interferes with competition by reducing the differences between different territorial units.

It is also advisable to use indicators to measure competitiveness - for the sake of more accurate comparability. Considering the fact that countless criteria, indicators and their weightings can be taken into account, we can apply several existing and proven practices ${ }^{8,9}$ within the scope of our research. One model for measuring the competitiveness of a region is the Lengyel pyramid model (Lengyel, 2010). In the model, the local environment plays a prominent role which reinforces our idea that examining this indicator brings us closer to the Industry 4.0. The Lengyel pyramid model identifies small and medium sized enterprises (performing basic activities) as the main factors that may improve the competitiveness of the given territorial unit directly and in a short term. They also can have a serious multiplier effect (Lengyel, 2010; Szerb, 2010).

The latest forms of post-Fordist economies can also be called knowledge based economies (Lengyel, 2010). A comparison of Fordist (or object based) economies and knowledge based economies appears in the works of Cséfalvay (2004), Enyedi (2012) and Rechnitzer (1998). With regard to the organization of the economy in post-Fordist regions, we can basically identify three types of regions (Lengyel, 2010):

- neo-Fordist (semi-periphery);

- knowledge applying;

- knowledge generating (central) region.

In fact, the knowledge generating region is an ideal embodiment of the objectives set out in the Fourth Industrial Revolution, as there are corporate clusters, close collaborations, and demand for highly qualified staff capable of meeting the requirements of $R \& D$ positions. These regions can produce their products tailored to individual needs in mass production, making the best use of the local conditions. The increase in the competitiveness of these regions is expected to be continuous and long-lasting. The primary goal for Hungary should be to move towards a knowledge generating region, which is also reflected in the Irinyi Plan.

Industry 4.0 ecosystem

Europe's industry of the $21^{\text {st }}$ century faces serious and complex challenges (United Nations, 2011, 2015). The expectation of increasing productivity, the opportunity for an expanding practice of mass customization, the need for the entire product life cycle to be sustainable, the broadening global competition, the increasing demand for highly skilled workforce and the demographic changes are all issues that require the adaptation of the current model in use.

\footnotetext{
${ }^{8}$ IMD World Competitiveness Yearbook http://www.imd.org

${ }^{9}$ The World Bank Doing Business http://www.doingbusiness.org/
} 
Companies have recognized the need for comprehensive solutions to respond effectively to these expectations (McKinsey \& Company, 2013). Indeed, many companies create alliances, where academic and university knowledge is often involved as well.

In 2013, in order to maintain and enhance the economic potential of the country, the German federal government embraced the cooperation of actors in science and economy at the political level, and announced the Plattform Industrie 4.0 programme, which provided a good institutional framework and a secure base for the cooperation of government, science and economy (Kagermann et al., 2013). Over the last few years, creating platforms has become a general practice of countries around the world. These thoughts can be recognized in some countries' industrial development, industrial digitisation policies, each of which prioritises the improvement of a country's competitive position by enhancing industry performance.

Several experts remind that it is not fortunate to restrict the interpretation of the Industry 4.0 phenomenon only to industry and new technologies (Bharadwaj, El Sawy, Pavlou, \& Venkatraman, 2013; Erol, Schumacher, \& Sihn, 2016; Szalavetz, 2015; Porter \& Heppelmann, 2014). A broader ecosystem approach is also represented to the concept. The key to competitiveness is the development of innovation capabilities. It can be observed that the spatial concentration and clustering of entities in the economic, academic and government spheres (known from the Triple-Helix model) facilitates the faster creation and diffusion of innovations (Etzkowitz \& Leydesdorff, 1997; Porter, 1998). Modern innovation is not carried out in research laboratories of large companies, but as a result of systematic cooperation between diverse, wide-ranging innovation systems.

Although the virtual space created by computer networks eliminates the distance between the partners involved in certain relationships, the physical location of the given economic actor (i.e. the country in which it operates) is by no means indifferent and irrelevant. The definition of innovation clearly points to its influence on the environment, the effects of the milieu and its dominant role - thus the innovation of Industry 4.0 companies is an important issue that has to be examined. As innovation influences regional development, the success of a region depends on the embeddedness of innovation systems (Rechnitzer \& Smahó, 2011). Competitive regions are the best suited for introducing innovative solutions. Cities, city networks and their inhabitants who are focused on spatial location have a key role. These actors together make up a large part of the territorial capital and influence the local innovation milieu.

In fact, the competitiveness of the region is an output - the input includes elements of its territorial capital. In Hungary, the process of reindustrialization (Lux, 2017) and digitization can be observed, in which the characteristics of companies (e.g. size, industrial location, international embeddedness) play different roles (Cristopherson, Martin, Sunley, \& Tyler, 
2014). The organizational, ownership related, technical, etc. innovations of the industry have had spatial consequences and formed the basis for regional studies (Barta, 2002; Barta, Czirfusz, \& Kukely, 2008; Cséfalvay \& Nikodémus, 1991; Horváth, 2000; Faragó \& Lux, 2014; Kiss, 2008; Kiss, 2013; Kiss, 2013, Molnár \& Lengyel, 2015).

\section{Transformation of the spatial structure of Hungarian industry}

The industrial legacy of the socialist system is characterized by an artificially high level of employment, it is diverse in terms of its level of development, fundamentally lagging behind, poorly adapted to the economic laws and territorially spread out. Besides the traditional industrial regions, fragmented industries scattered over nation wide is determinant, which was created by the large companies who outsourced their low-level activities into towns. Simultaneously, Hungary had an overcentralized industry, whose internal relationship networks have been largely constructed artificially, ignoring geographical logic (Barta, 2002, Kiss, 2010). Furthermore, the transport, communication and commercial infrastructure did not meet the market economy expectations of the age. At the same time, however, a significant amount of skilled workforce and a fairly established institutional system brought positive benefits as well. Under these circumstances, the Hungarian industry was in a fundamental crisis at the time of the political changes in 1990 (but that started already developing in the early 1980s, together with the entire Eastern bloc).

With the break-up of former COMECON relations, the old export markets almost disappeared. In such circumstances, the capital-poor industry had no choice but to build on the inflow of significant foreign direct investment during the privatization process, and thus adapting more advanced technologies through a network of trans- and multinational companies and also reaching new markets. Most of the industrial production is now exported (according to the $2018 \mathrm{KSH}^{\mathbf{1 0}}$ data, $73 \%$ of manufacturing sales are directed abroad), in which the later, typically green-field investments in the machinery sector play a significant role.

Capitalist companies have placed great emphasis on improving productivity, resulting in the stagnation or a slight decline in employment in the country, despite the growing industrial output since the 2000s. Overall, during the last two decades, Hungary seems to be lagging behind the former socialist countries joining the EU, in terms of the pace of industrial growth (Nagy et al., 2019), while the share of foreign direct investment in the economy is the highest here (KSH, 2017). The key issue for the country's industrial development lies in the responses to the challenges of Industry 4.0, and whether it will succeed in moving towards higher value-

\footnotetext{
${ }^{10}$ Central Statistical Office (Központi Statisztikai Hivatal, in Hungarian)
} 
added activities in global and European value chains. (Szalavetz, 2016a, 2016b, Irinyi Plan). After a stable industrial structure of the decade preceding the regime change, a marked differentiation process started at the county level from the 1990s on (Nemes, Nagy, \& Löcsei, 2015). The effect of the inflow of foreign direct investment was first manifested in the northwestern part of the country and the capital, from the early 90 s on.

Later - partly as a result of the motorway constructions - foreign capital appeared in other regions as well, and as a result, reindustrialization started. The detailed analysis of the factors influencing the spatial structure of the industry after the regime change (from human resources through industrial parks to clusterization) is provided by Éva Kiss (2010). This process seems to reproduce the spatial relationships typical for the socialist past, i.e. the traditional NorthSouth division, which is associated with path dependence theory of evolutionary economic geography by Molnár \& Lengyel (2015), and visualized in Figure 1. In addition to the advancement of the north-western region after the regime change, during the throw-back of the northern peripheral basins and the industrial centre of Mecsek, reindustrialization tendencies can be observed in the areas of the Great Hungarian Plain near the capital (from Hatvan through Jászság and Szolnok to Kecskemét) and in some county seats, more recently in Debrecen. Our analysis also provides indirect evidence for the industrial devaluation of rural areas.

Figure 1 The industrial axis in the reshaping

\section{Renewal of the industrial axis: change or stability?}

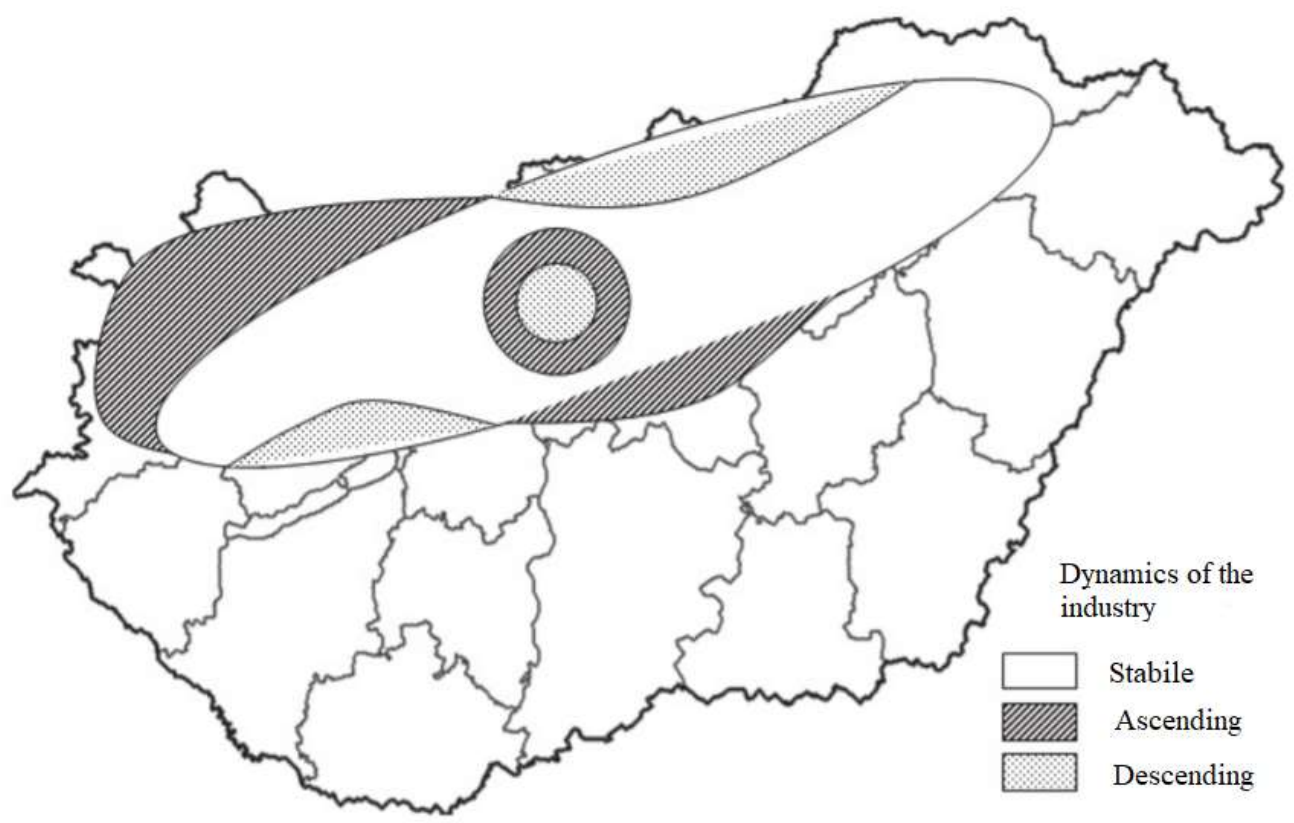

Source: Molnár and Lengyel (2015)

The dualism of industry and of the entire Hungarian economy can be described with the dichotomy of the 
- capital intensive, technologically advanced large corporations that produce a significant proportion of the GDP and export revenue,

- and the domestic SMEs that are forced to adapt to the circumstances and produce for the internal market, possibly acting as suppliers (Lux, 2017).

The image is further modulated by some successful domestic big companies (e.g. the pharmaceutical industry), by the often domestically owned food industry, the declining metal processing industry (which is becoming more and more involved in the supply chains and is dominated by SMEs) and the labour intensive TCLF sector, which is looking for its place in niche markets of special products and as vehicle industry suppliers (Molnár, 2017). Cséfalvay (2004) sees the low level of cooperation between the two sectors as the most important problem with the dual structure. This situation has only slightly improved since then, so spill-over effects are also weaker than expected. Economic dualism turns up in the spatial structure, too, as large foreign companies have greater space-forming capabilities (Lux, 2017). In the Northern TransDanubian area, where many foreign companies have been present for a long time, more and more diverse production links are emerging - mainly in the automotive industry - and the benefits of agglomeration are increasingly to be seen. In contrast, most parts of the Great Plain and Southern Trans-Danubian area are dominated by domestic-owned companies with fewer options. Here, the weight of the industry is smaller, and foreign plants are appearing sporadically only. On the basis of the trends so far, it can be stated that in the externally controlled industrial development model, building the relationships takes a long time, and the newly joined regions have all to struggle through the same path. Notwithstanding, it is only partially possible to catch up with the West this way. The possibility to accelerate this model, or an alternative for it, with perspectives of upgrading should be found in industrial digitalization, which shows increasing integration and accelerating processes, reactions.

\section{Geographical effects of Industry 4.0}

The potential spatial effects of the fourth industrial revolution have been recognized by researchers, including Porter and Heppelmann (2014), Khajavi et al. (2014), or Roland Berger (2016b). In Hungary, Andrea Szalavetz (2016a, b) can be mentioned. Strengthening vertical and horizontal integration as a key feature of Industry 4.0, project the drastic transformation of the entire value chain. For example, subsidiaries or suppliers may gain new features, which could lead to upgrading, but reassessment the viability of individual functions is also possible. Based on Szalavetz's (2016b) research, tendencies are not yet clearly promising. Although 
many new functions appear in the Hungarian subsidiaries, this often happens with the general weakening of their position in the value chain (they move towards the bottom of the smilecurve). Reshoring or nearshoring are possible consequences of Industry 4.0. Fashion industry provides some examples of this phenomenon due to the rapidly changing market (Laseur, 2019). Broadening and deepening horizontal and vertical integration and creating the new ecosystem are the main motivations for increasing clusterization.

Indicators such as the Roland Berger Industry 4.0 Readiness Index or the Digital Economy and Society Index (DESI) allow for a comparative assessment of countries. Hungary shows quite mixed picture, but in total there is no significant lag behind the EU average (Pongrácz \& Nick, 2017). One relevant strategic goal for the Hungarian industry is to step over to the group of Frontrunners from the Traditionalists in the Roland Berger categorization (Roland Berger, 2016a). By linking micro- and macro-level investigations, sectoral or regional studies may also be possible (e.g. Losonci et al., 2019).

\section{DATA AND METHODS}

The empirical research aims to map the Hungarian Industry 4.0 ecosystem. What are the differences in the technical readiness of individual companies? How does the location of the area affect the strategic characteristics of each actor? In order to get to know the current situation and the planned future thoroughly, it is necessary to assess:

- the current status of Industry 4.0 awareness, acceptance and implementation;

- the R\&D\&I cooperation potential;

- the competitiveness potential and conditions;

- relevant challenges for human resources, that is, the overall spatial effects of industrial digitisation.

For this reason, we perform the primary analysis on the data from the survey of the Industry 4.0 National Technology Platform. Besides the geographic position, other aspects characterizing the dualistic economy are investigated, to provide the potential basis for explanations. For the questionnaire itself, the research process and methodology used, as well as its detailed structure and general results, see Nick, Szaller, Bergmann, \& Várgedő (2019) and Nick,Várgedő, \& Fülep (2018).

The size of the sample was limited, thus the analysis had to be performed on a rather small population of groups, so the results are to be interpreted with caution. 


\section{Territorial categories used in the analysis}

The interpretation of the territory related results of the questionnaire is done on a county scale. Considering that generally only a few data are available at the county level, they are grouped by industrial geographic factors. The analysis was executed based on this categorization. The purpose of this work was to create categories representing the dualistic structure of the industry that fit the analytical results and provide also a tool to demonstrate the spatial structure of the Hungarian industry.

The basis for the categorization was the regional data of the HCSO in $2017^{11}$. The categories are created using the measure of industrial production per employee (in any field of economy) in the county. In contrast to labour productivity, this indicator has its advantages in reflecting both the weight and the level of development of the industry. County level indicators are related to the one of the whole country. In the following formula used to determine the categories for the counties $\mathrm{p}_{\mathrm{i}}$ denotes the industrial production of the individual county $i$, while $\mathrm{p}_{0}$ denotes this value for the whole country, $\mathrm{e}_{\mathrm{i}}$ and $\mathrm{e}_{0}$ are all the number of employees of the county $i$ and the country, respectively. The indicator (I), which is the basis of the categorization can be computed on the following way:

$$
I=\frac{p_{i} / e_{i}}{p_{0} / e_{0}}
$$

From Table 1 one can see the clear separating line between counties that are above and below the national average. On this basis, we can distinguish between industrialized and less industrialized counties. This indicator is well aligned with other indicators related to the dual structure of industry, such as productivity (million HUF / employee), the export orientation and the weight of the machinery industry. An exception is Nógrád, where the weight of the industry is small, distorted by some foreign actors. Somogy has to be treated differently because of some companies like Flextronics in Tab, that have their headquarters here with all their production being recorded here while having a net of production sites in other counties. With the help of the local business tax and corporate production data, we obtained upper estimates for industrial production in this county, and it has turned out that half of the county's official production is not performed there. Accordingly, the table contains a reduced value. The opposite is true for Zala: the number of companies with non-local seats (e.g. Tungsram, Flex) are considerable,

\footnotetext{
${ }^{11}$ http://www.ksh.hu/docs/hun/xftp/megy/184/index.html\#
} 
however the former method is not applicable. In any case, it is doubtful that Zala would ever become one of the first counties from its current last place.

Table 1 The indicator compared to other relevant data

\begin{tabular}{|l|c|c|c|c|}
\hline \multicolumn{1}{|c|}{ County } & Indicator & Productivity & Export rate & $\begin{array}{c}\text { Weight of machine } \\
\text { industry }\end{array}$ \\
\hline Györ-Moson-Sopron & $288 \%$ & 73232 & $91 \%$ & $43 \%$ \\
\hline Komárom-Esztergom & $275 \%$ & 60050 & $84 \%$ & $49 \%$ \\
\hline Fejér & $214 \%$ & 60779 & $83 \%$ & $38 \%$ \\
\hline Heves & $185 \%$ & 61058 & $90 \%$ & $35 \%$ \\
\hline Bács-Kiskun & $185 \%$ & 65628 & $81 \%$ & $33 \%$ \\
\hline Vas & $163 \%$ & 41040 & $88 \%$ & $41 \%$ \\
\hline Borsod-Abaúj-Zemplén & $158 \%$ & 72547 & $79 \%$ & $25 \%$ \\
\hline Jász-Nagykun-Szolnok & $157 \%$ & 49764 & $83 \%$ & $34 \%$ \\
\hline Veszprém & $131 \%$ & 39002 & $80 \%$ & $38 \%$ \\
\hline Pest & $77 \%$ & 37210 & $71 \%$ & $26 \%$ \\
\hline Nógrád & $69 \%$ & 28270 & $89 \%$ & $27 \%$ \\
\hline Somogy & $63 \%$ & 46303 & $86 \%$ & $29 \%$ \\
\hline Hajdú-Bihar & $55 \%$ & 32122 & $72 \%$ & $19 \%$ \\
\hline Csongrád & $53 \%$ & 25904 & $63 \%$ & $23 \%$ \\
\hline Szabolcs-Szatmár-Bereg & $52 \%$ & 25105 & $75 \%$ & $22 \%$ \\
\hline Tolna & $47 \%$ & 22774 & $69 \%$ & $24 \%$ \\
\hline Budapest & $46 \%$ & 46259 & $62 \%$ & $11 \%$ \\
\hline Békés & $42 \%$ & 21959 & $62 \%$ & $23 \%$ \\
\hline Baranya & $37 \%$ & 26266 & $64 \%$ & $18 \%$ \\
\hline Zala & $32 \%$ & 16868 & $53 \%$ & $23 \%$ \\
\hline
\end{tabular}

The two basic categories were further differentiated based on geographical considerations. On the one hand, we distinguished between the Western (in Trans-Danubia, blue in Table 1) and the Eastern (on the East of the Danube, green) categories, which is not only justified by topographical reasons, but also that reindustrialization started later in the green zone. On the other hand, the separation of the capital region (the Central Region with red) is definitely necessary, since this city and its surroundings - being the only metropolitan area in the country - define quite different conditions for the economy. Lastly, the less industrialized counties were divided into knowledge centres (where the regional centres for large universities operate, with orange) and peripheral counties (yellow) following Lengyel and Varga (2018). County categories are shown on the map of Hungary in

Figure 2. 
Figure 2 Counties in Hungary - categorised

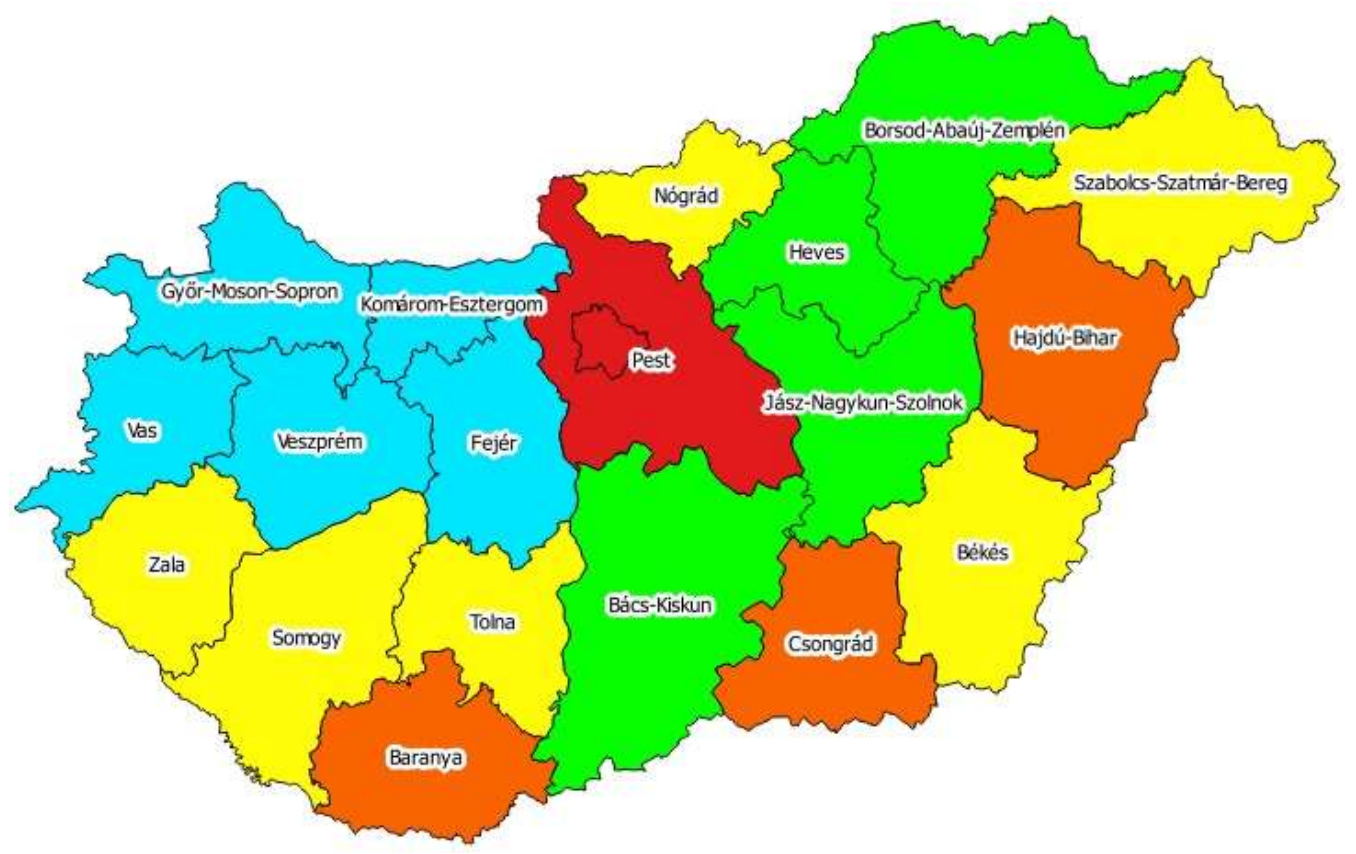

RESULTS AND DISCUSSION

The characteristics of the sample based on background issues

Table 2 Number of companies in the manufacturing sectors by regions with the number of completed questionnaires

\begin{tabular}{|l|l|l|l|}
\hline Region & Number of companies & $\begin{array}{l}\text { Completed } \\
\text { questionnaires }\end{array}$ & Filling rate \\
\hline Centre & 19133 & 59 & $3,1 \% 0$ \\
\hline West Ind. & 7008 & 42 & $6,0 \% 0$ \\
\hline East Ind. & 6289 & 28 & $4,5 \% 0$ \\
\hline Knowledge centre & 4382 & 22 & $5,0 \% 0$ \\
\hline Periphery & 5416 & 17 & $3,1 \% 0$ \\
\hline
\end{tabular}

In the development of county categories, besides of applying the industry-focused logic, we also tried to obtain categories with a significant number of answers in each. This is only partially met in the case of less industrialized counties, thus the responses from knowledge centres and periphery - although shown separately in the representation - are often treated together. The number of items in each county category does not show a noticeable deviance in their tendency 
from what the professional logic would predict for the spatial distribution of companies involved in Industry 4.0 - this supports their usability in the analysis. The pattern seems to be less concentrated around the centre than the industry, by the way, it is logical that on the periphery, fewer companies are included than in the region that is leading in reindustrialization. In the following diagrams, one can see some features in connection with the group of survey participants for each territorial category, which are important for later analysis. In each county category, enterprises are mixed in terms of the number of employees. Smaller companies are more prevalent in the central the knowledge centre counties. Microbusinesses can only be found here, which can be partly explained by the close concentration of companies carrying out softer industrial activities (e.g. consultancy) near the universities.

There is no striking difference regarding the ownership. We have added some of the majority owned companies to the ones of exclusive foreign and Hungarian ownership. On the periphery, the somewhat smaller number of foreign participants are in line with the lower presence of foreign direct capital in these counties. The higher proportion of Eastern industrialized counties may be explained by the regional supplier network and relationships that are less developed due to the temporal delay vis-a-vis their Western counterparts. In the international production cooperation - as expected - the Western industrialized counties are most likely to be involved, while in the peripheral counties this is somewhat less typical. In Figure 3 and Figure 4, one can see the distributions of the respondents by these factors (small company: up to 50 employees, middle: 51-250 employees, large: more than 250 employees).

Figure 3 Results of the questionnaire

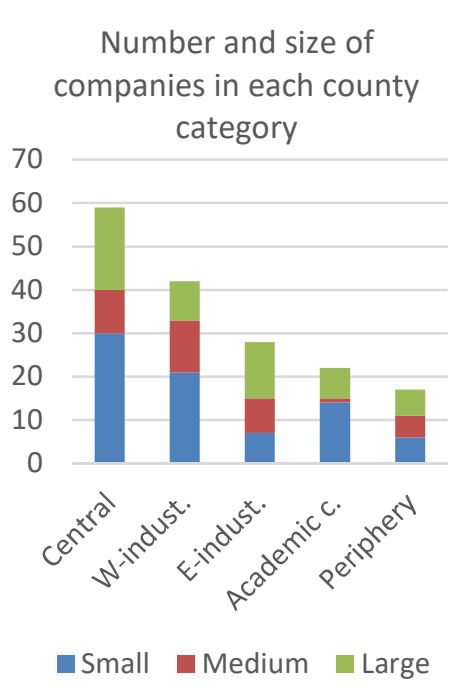

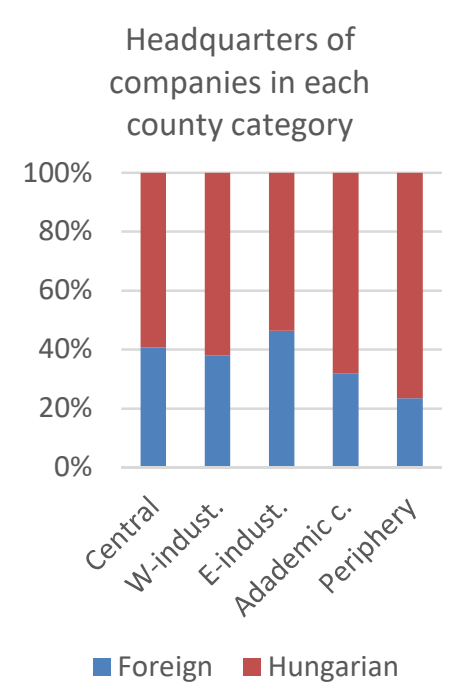

Headquarters of companies in each
Proportion (\%) of companies participating in international cooperation in each county category

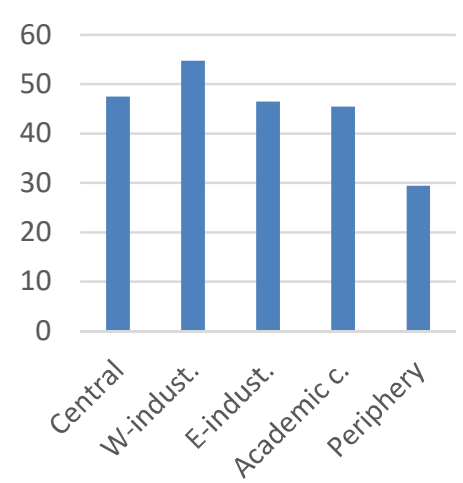


Figure 4 Number of companies in each industrial sector and county category

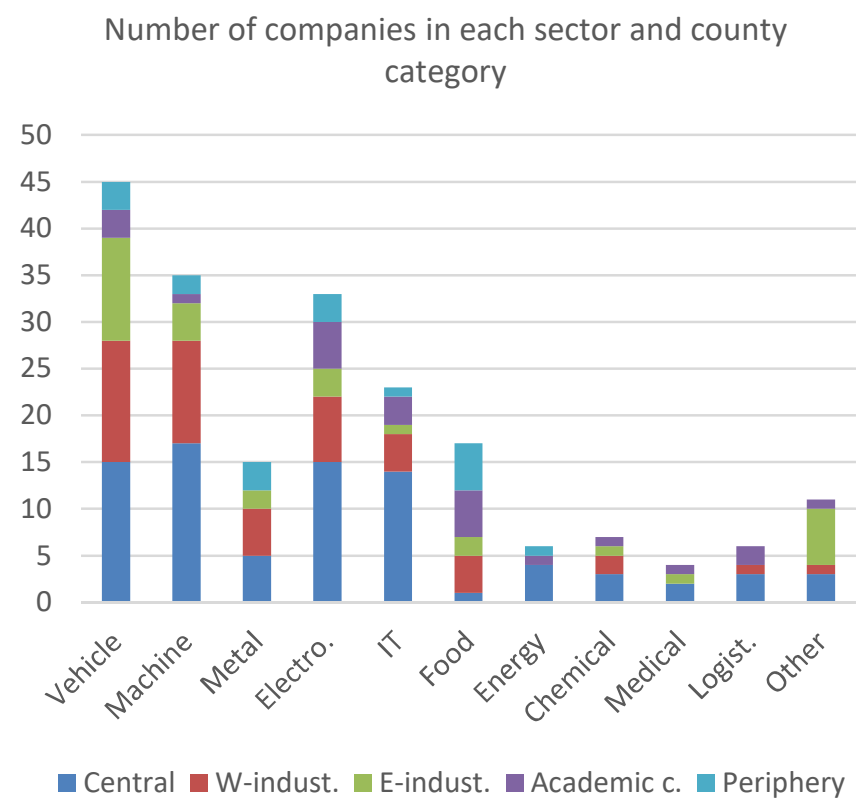

The sectoral breakdown of the companies that participated in the questionnaire clearly shows the predominance of the machinery industry, as expected in an Industry 4.0 online questionnaire. Out of the 168 respondents, 14 did not designate any category, while there were also several participants who marked two or more activity types that generally do not contradict a consistent portfolio (e.g. vehicle industry + machine industry in 9 cases, machine industry + metal industry in 6 cases, electronics + ICT in 6 cases). In the following, we will consider all companies with the same weight in the sector analyses that have marked a given activity, as there is no basis to assume that they do not carry the sector's characteristics. The populations in the sample provided an opportunity to examine the vehicle, machinery, metal, electronics and food industries, and the ICT sector as well. From a territorial point of view it can be stated that the weight of the activities related to the machinery industry is the highest in the Western industrialized counties (vehicle, machine, metal, electronics industry together account for $75 \%$ of total industrial production), and the lowest in the knowledge centre counties (40\%). The automotive industry is the most common in the Eastern industrialized counties, while the food industry is typical in the two groups of counties that are less affected by reindustrialization. The increased weight of the ICT sector in Budapest and somewhat in the knowledge centre counties is conspicuous and logical.

Other sector specific features of the sample refer to the fact that in the food industry, domestic large companies; in the ICT sector, small businesses are the most typical. Domestic 
property dominates in the metal industry, while the share of foreign ownership is relatively higher in the automotive and electronics industries - here both small and large companies are frequent. International production cooperation in the food industry hardly exists and is not common in IT companies either, but is very typical in the automotive industry, and also more than half of electronics and machine manufacturers cooperate with producers of other countries.

According to some additional background surveys, the share of domestic ownership is very high in the case of medium-sized companies (80\%), this value is little higher than $60 \%$ for smaller companies, and 50\% for large enterprises. By the way, the division of companies into this three categories has shown interesting results in other cases as well. Medium-sized companies have repeatedly shown results that are analogous to large businesses, while in other cases they have been completely different from small and large companies. In international production cooperation, foreign companies clearly participate more often (64\%) than domestic ones $(37 \%)$.

In this study, we also compare spatial aspects with others (industry, company size, ownership). Considering that the online questionnaire is more likely to be filled in by companies who are more concerned with, and affected by Industry 4.0, we are not focusing on the exact extent of their variance. These are only used to indicate qualitatively the regional (and other) differences. More preferably, we concentrate on exploring the economically relevant environment (human resources, infrastructure, barriers, etc.), which offer the opportunity to draw well-generalizable consequences. The background data presented above provide a variety of aspects for analysis.

\section{Innovativeness}

When the participants were asked whether the company introduced a new or significantly improved product / service or process / method, the possible answers were "no", "less than 5", "5-10", "more than 10". These are depicted in the diagrams of Figure 5 by different background categories (area, size and sector). Although the trend draws the advantage of large companies, it is still difficult to imagine how a great number of these companies could be operating for 5 years without adding a new product to their portfolio or introducing innovations in their production processes. The subjectivity of self-declaration and possible differences in the interpretation of concepts can distort the results. Foreign-owned and international companies perform somewhat better. From the sector perspective, IT seems to be the most innovative, the 
food industry shows some lags in terms of processes and methods. In the metal industry, the product portfolio is changing faster, which may be due to its supplier role. Neither the vehicle and machine industries nor the electronics are standing out clearly, although this may partly be attributable to their large weight in the sample. From a regional point of view, the lack of peripheral counties is not surprising, but in contrast to the high value of the knowledge centre counties, the only average performance of the central region is considerable and needs further investigation.

Figure 5 Product and process innovation
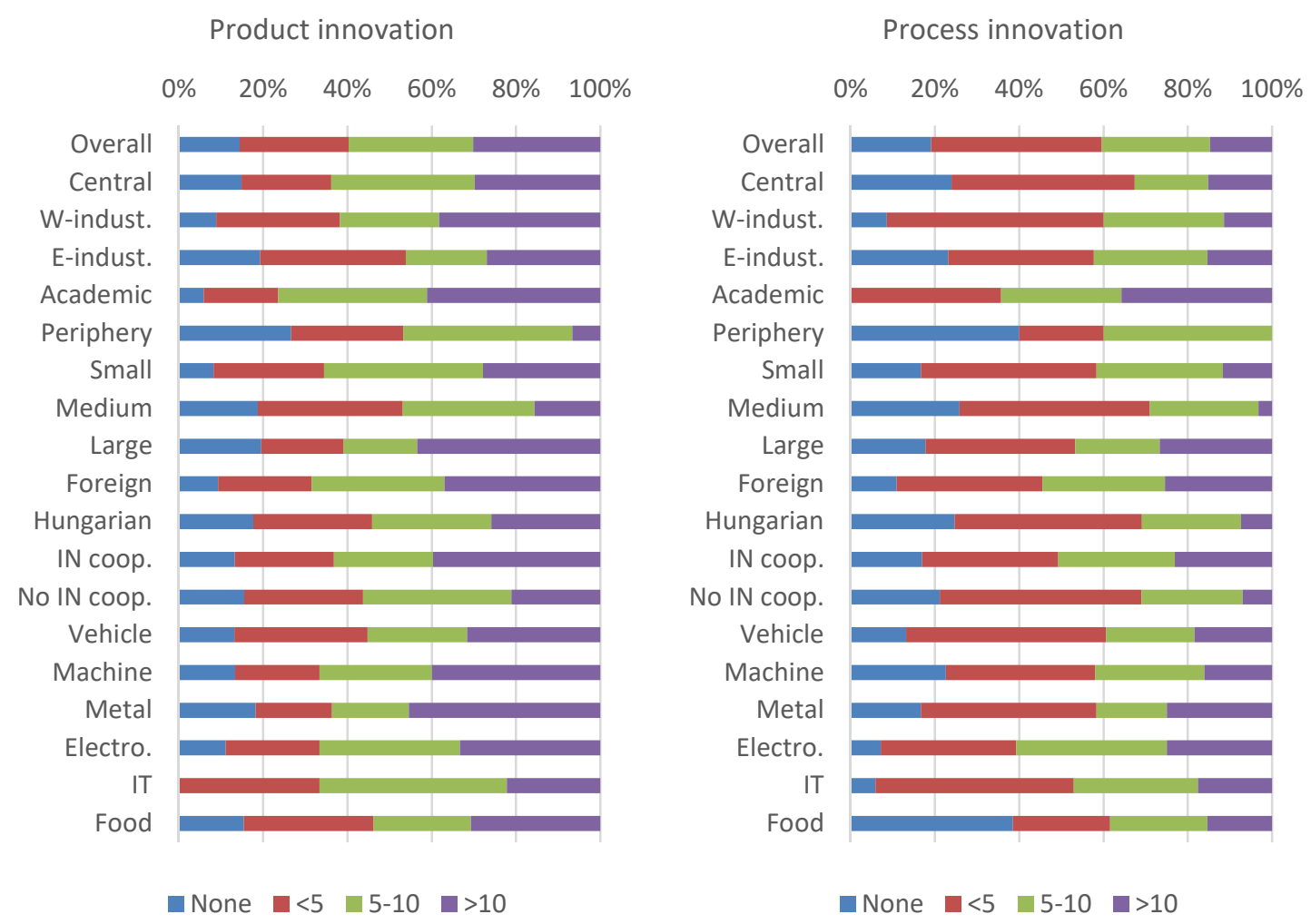

Strategy

The state of the strategy can be a relatively general indicator of the industry's readiness related to Industry 4.0. From this point of view, we cannot see sharp territorial differences, but the Western industrialized counties are at the forefront, and the periphery has the least advanced state of the strategy. It is also noteworthy that companies in the knowledge centre counties theoretically seem also to be quite ahead, while none of them has come to implementation yet (see

Figure 6). 
Figure 6 Status of existing strategy if any, for Industry 4.0

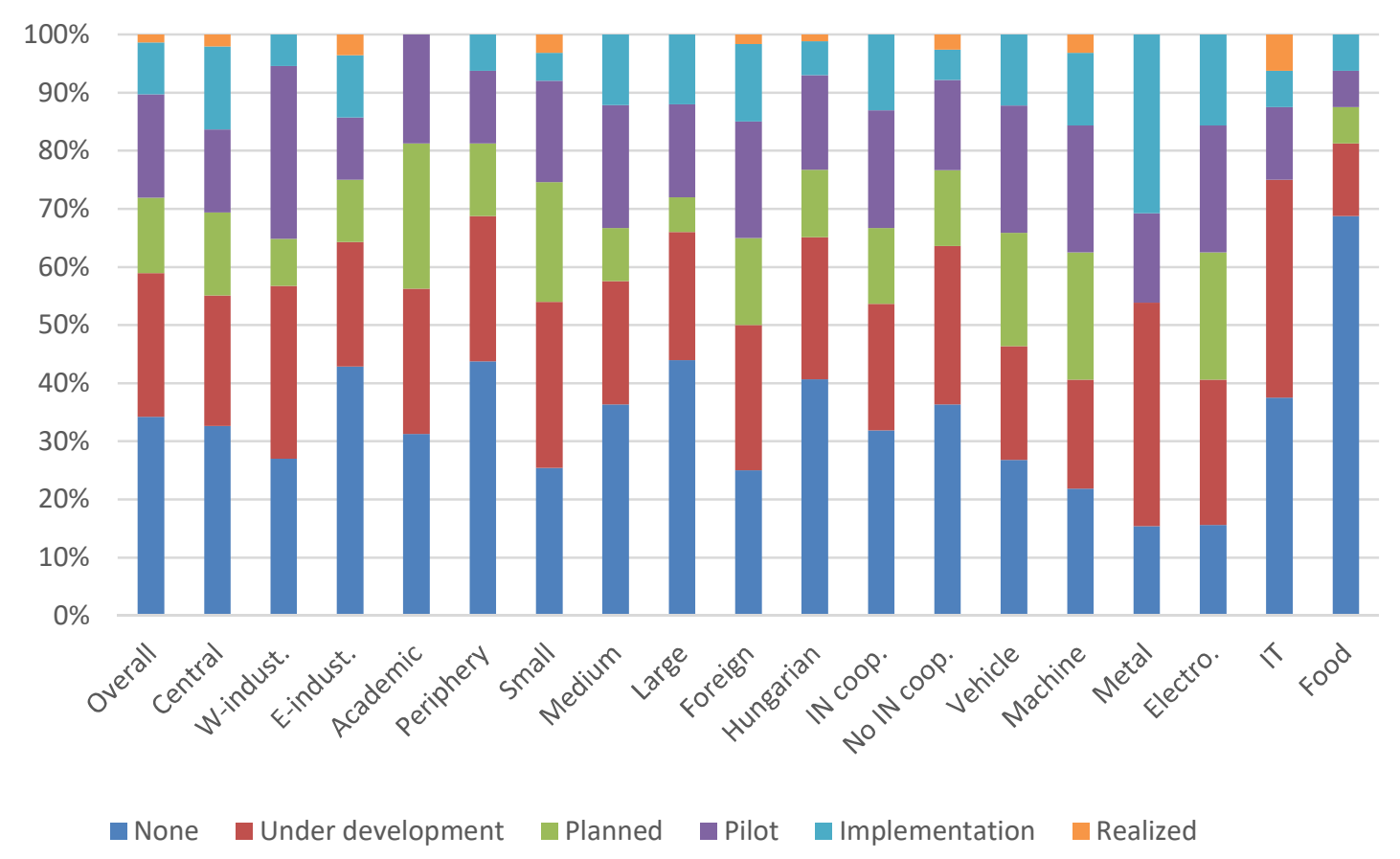

Apparently, there exists a negative correlation between the size of the company and the state of the Industry 4.0 strategy. On the one hand, this might be due to the larger inertia, and more cautious program creation and communication of the larger organizations, but at the same time one should not forget that the food industry is overrepresented among the large companies, and the food industry's interest in Industry 4.0 is obviously much lower. It is also evident that foreign companies and those active in international collaboration are moving forward more speedily, underpinning the thesis that the technological development of the country is rather controlled from outside. Besides the serious disadvantage of the food industry's position - as expected other key sectors (especially electronics) perform substantially better in Industry 4.0. In the case of the metal industry, perhaps the less complex activity spectrum may be the reason why they can more easily develop and implement an Industry 4.0 strategy (they do not appear to be a leader by other aspects). In the case of the ICT sector, an Industry 4.0 strategy may probably not always be defined for the company itself, because of its main role as a service and support provider. This assumption is also confirmed by the technological data.

\section{Technologies}

Sectoral trends should be looked at first, because they are determinant in the evaluation of other aspects. Evidently, the automotive industry and machine manufacturing are showing similar trends in technological preferences, which are more or less in line with the electronics industry, 
too. Sensors, mobile terminals, radio frequency identification and M2M communication are more frequently used, showing the relevance of smart manufacturing in the forerunners' sectors. Horizontal system integration is the most widespread in the automotive, machinery and metal industries participating in extensive supplier networks, thus the higher ratio of MES / ERP / PPS is understandable. Currently, IOT, Big Data, Cloud, and AI applications are dominated by representatives of the ICT sector, while AR has not entered the Hungarian industry at all, which is obviously not a peculiarly Hungarian feature, but is rather due to the current immaturity of the technology. In overall, the food industry and the metal industry are lagging behind the other sectors in the diversity of implementing Industry 4.0 (see Figure 7 and Figure 8).

Figure 7 Distribution of each technology (\% ratio of companies that adopt it) per company characteristic

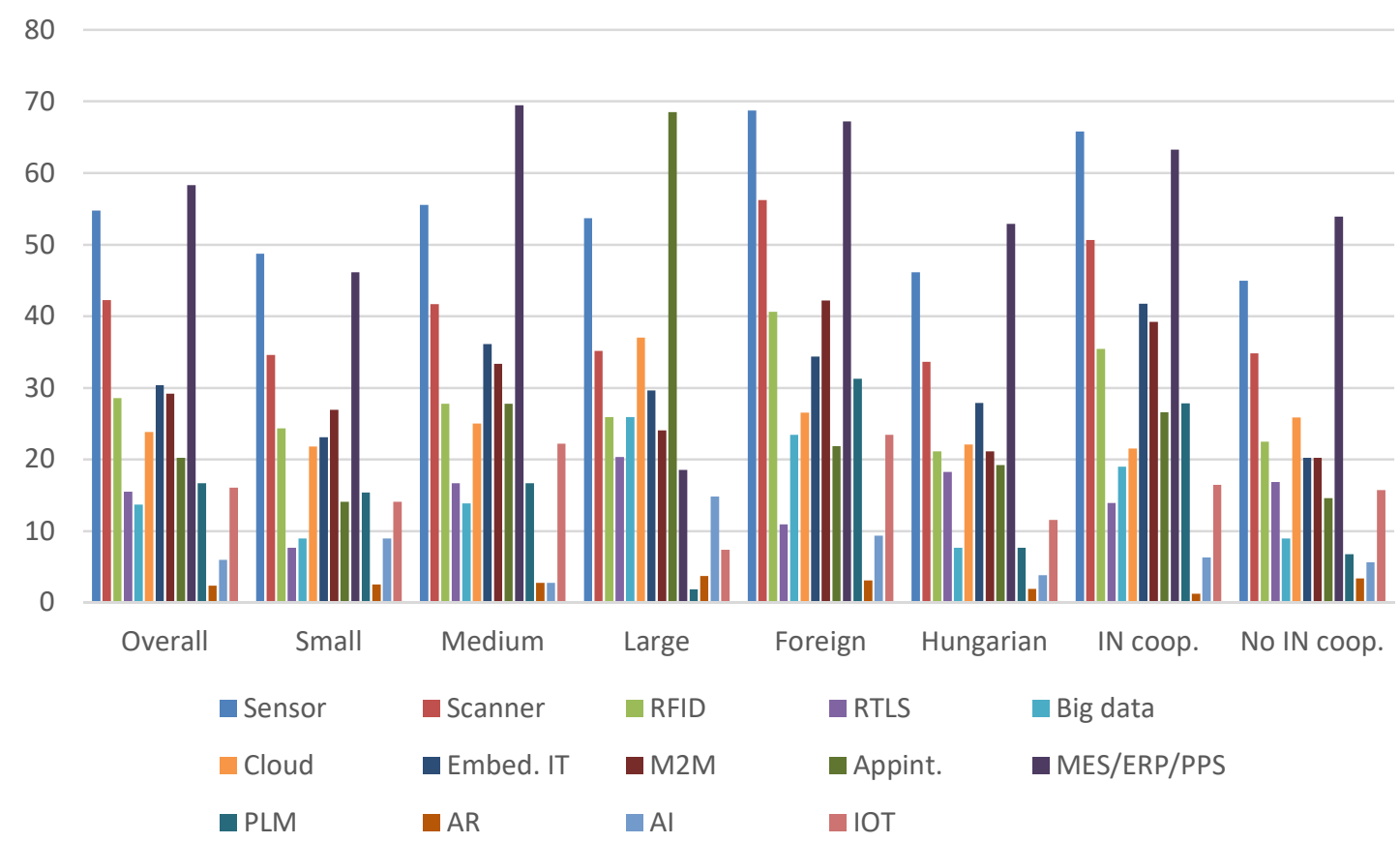

With the size of the company, the frequency of applying the I4.0 technologies usually increase, which, however, cannot only be considered as an intense development trend, but can also be explained by the more diversified solutions that are derived from the more diverse range of tasks caused by the larger size. The strong positive relationship between application integration and enterprise size may be due to the wider supplier network, while MES / ERP / PPS systems are more difficult to implement for a large company, and raise issues of security and competence, like in the case of industrial internet. There are similar trends in foreign-Hungarian aspect and international production cooperation as seen earlier, thus increasingly reinforcing the preconception of the dual economy. 
Figure 8 Distribution of each technology (\% ratio of companies that adopt it) per county group

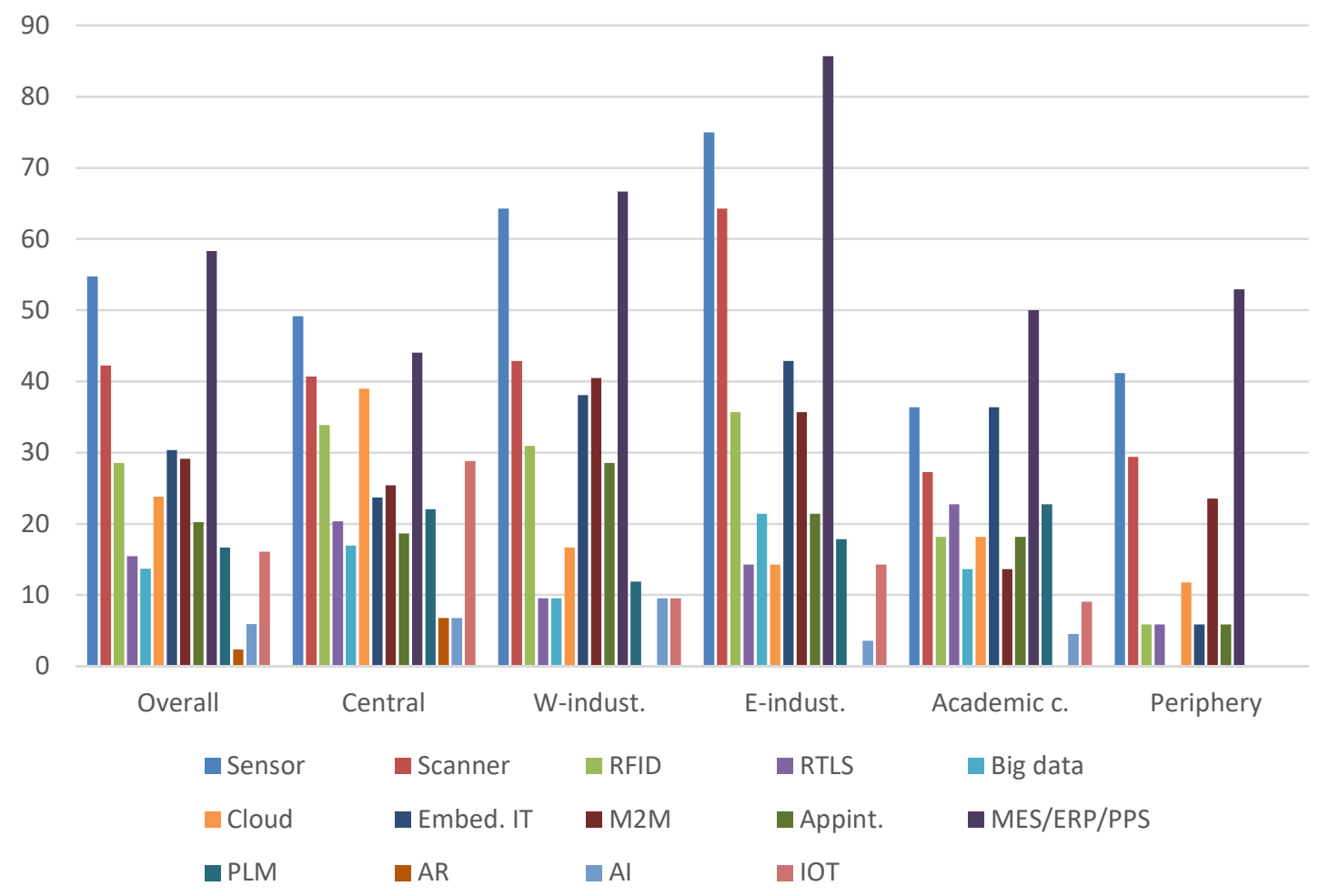

Here, at the regional level, the duality of the industrial spatial structure can be clearly determined, as both categories of counties in the industrial periphery are underperforming the others. Interestingly, it is not the Western, but the Eastern industrialized counties that are standing out. This can be caused (beside random effects) by the fact that generally larger companies are included in the sample, with a higher proportion of foreign companies. In the central region, we can see again the characteristics of IT companies dominating, but this region is behind the reindustrializing regions in general. This is also in line with the macroeconomic data, as the productivity of the manufacturing sector in Budapest and Pest county is below those most affected by industrial activity (see Table 1).

\section{Assessing the role of the key I4.0 technologies in the future}

Companies see the opportunities in I4.0 technologies, but in many cases they don't utilise them yet. Exploring the underlying causes is important: it requires qualitative research. Even in the case of the technologies, that were assessed less relevant now, more than half of the respondents believe that it will be important in the future, yet it is surprising that the weakest result is related to artificial intelligence, as this would probably have the widest future impact of all technologies ${ }^{12}$. Undoubtedly, the future of this is probably the least predictable. Based on the

\footnotetext{
${ }^{12}$ At the time of the survey, the Hungarian Artificial Intelligence Coalition, initiated by the Ministry, was not set up yet. Its aim is to bring together companies that apply $\mathrm{AI}$ and to facilitate the dissemination of this technology.
} 
results, the food industry will probably be less technology oriented in the future. Otherwise, no significant trends were found in the geographical or other aspects. All technologies in the capital region perform better, while the peripheral ones are more subdued (see Figure 9).

Figure 9 Relevance of technologies in the future per sector (ratio of answers: 'a priority issue' and 'of high priority' added up)

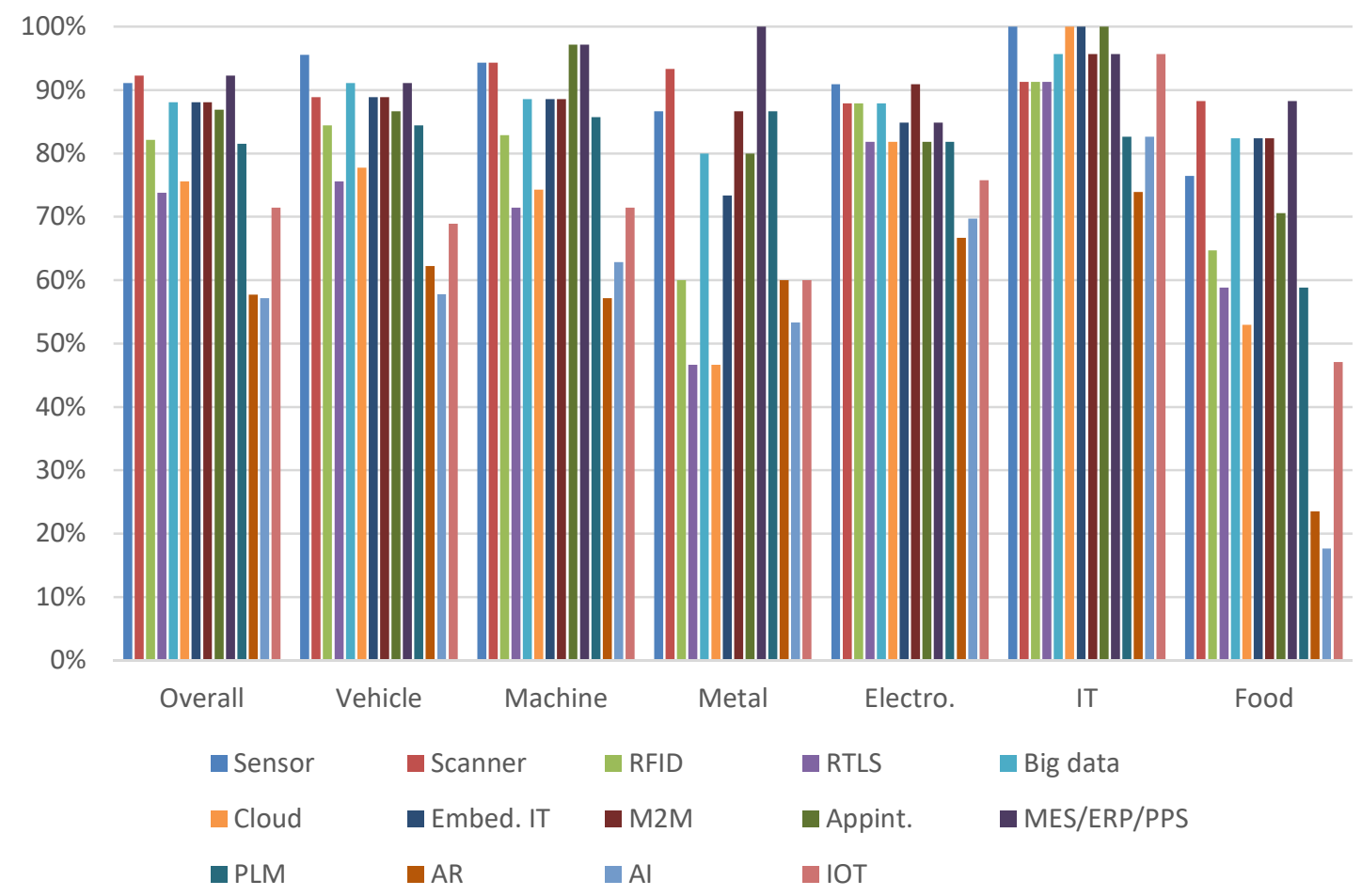

Robotization

Figure 10 Importance of robotization

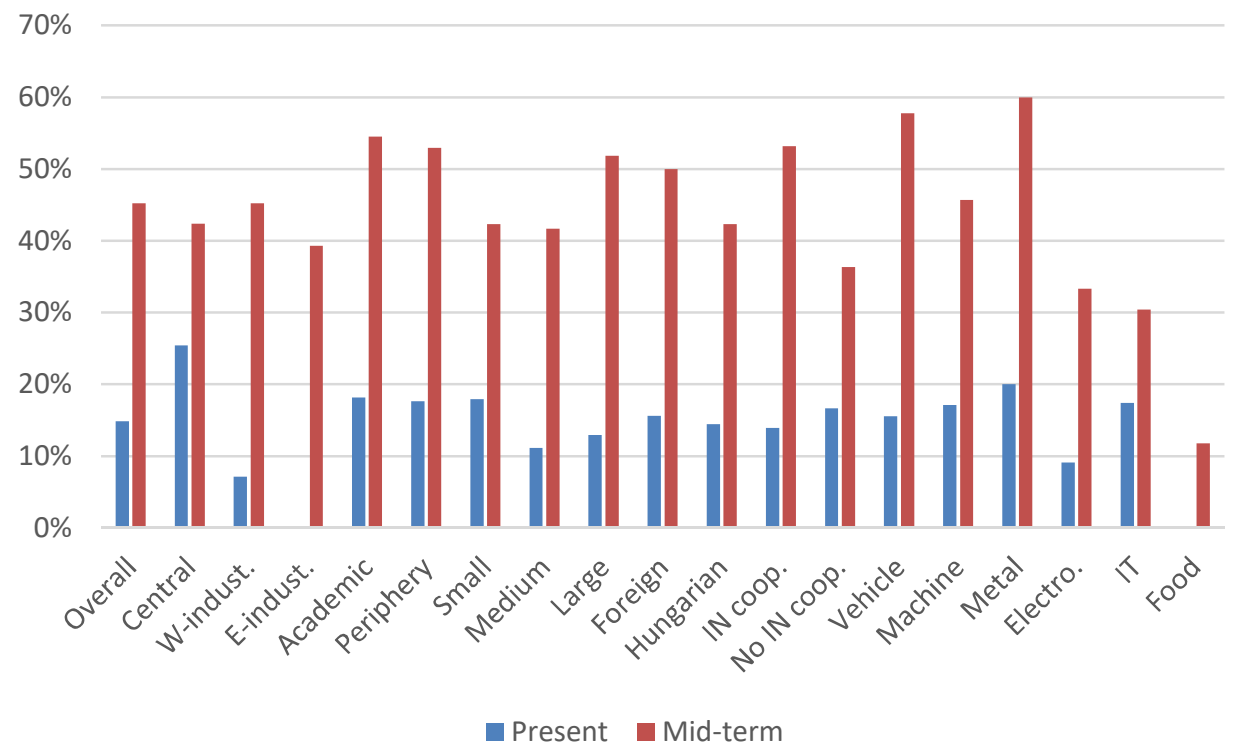


Chyba! Nenalezen zdroj odkazů. shows how many percent of respondents believe that the usage of robotics in their industry is largely or completely typical in the present (2017) and will be that in the near future (2018-20). First of all, it is a surprising fact that only $15 \%$ of the companies currently see robotization as a typical trend. The fact that in the medium term a significant jump is assumed by them, refers to excessive techno-optimism and raises the question of why there is such a discrepancy between vision and reality. Our previous experience in the literature further contradicts the fact that in the automotive industry, where the typical robotic density exceeds by one order of magnitude that of the other sectors (IFR, 2018), respondents attribute almost the same importance as the average to this technology. In the electronics sector, which was the second most robotized among the sectors, the importance is below average. The high proportion of the 'in certain areas' response, in connection with humanrobot collaboration recently emphasized by the companies, and the assumption that robotics is concentrated in some large, primarily assembly-related actors with low weight among the respondents, are the key factors in resolving this contradiction. In electronics, tasks requiring more sophisticated manipulation are more typical, which are difficult to robotize. Neither supporting nor disproving possible explanations is viable on the basis of these data. In the metal industry, the role of robotics is considered to be higher than average, while the technology is considered completely marginal in the food industry, and consequently, it is currently not applied.

From the territorial point of view, the use of robotics is the lowest in the Eastern reindustrialized counties, but it is barely better in their Western counterparts, the interpretation of which goes beyond the competence of the writers of this article. The higher value of the central region may indicate efforts to replace more expensive labour.

\section{Human resources}

Companies have also assessed the competencies of their employees according to some relevant aspects of Industry 4.0 (IT infrastructure, automation techniques, data evaluation, data security / communication security, development and use of support systems, teamwork applications, and non-technical competencies such as systems and process approach). The four-level scale spans from "does not exist" to "relevant and outstanding". The responses are assigned the values 0,1 , 2,3 , respectively, the averages are shown in

Figure 11 and Figure 12. In general, a low level of satisfaction can be unequivocally identified. 
Figure 11 Evaluation of the employees' competences per county group

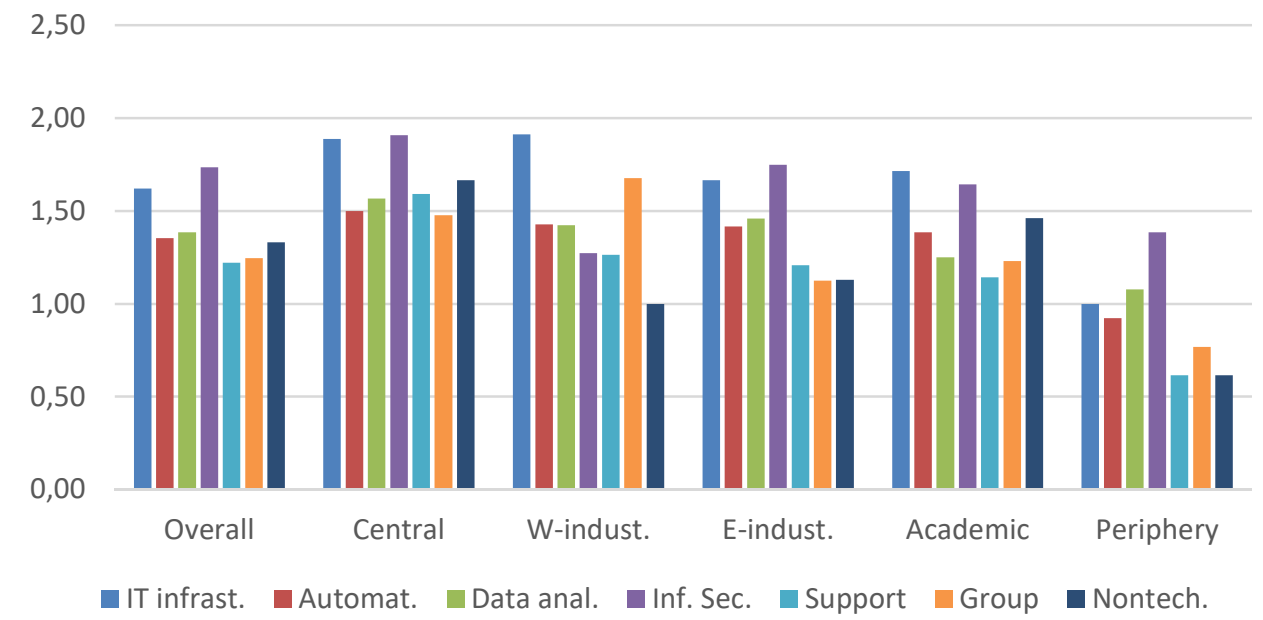

Employers' satisfaction with the competences of the workforce is clearly the largest and most balanced in the central region, and the smallest on the periphery. In detail, the northwest counties deviate from average in the positive direction in terms of teamwork applications, and deviate in the negative direction from the point of view of cybersecurity. This can be explained by the diversity of employee competences as well as by the employers' expectations. In knowledge centres and in the central region, companies are more satisfied with non-technical competencies, what is in direct connection with the role of higher education (in all fields) in these areas.

Figure 12 Evaluation of the employee competences per sector

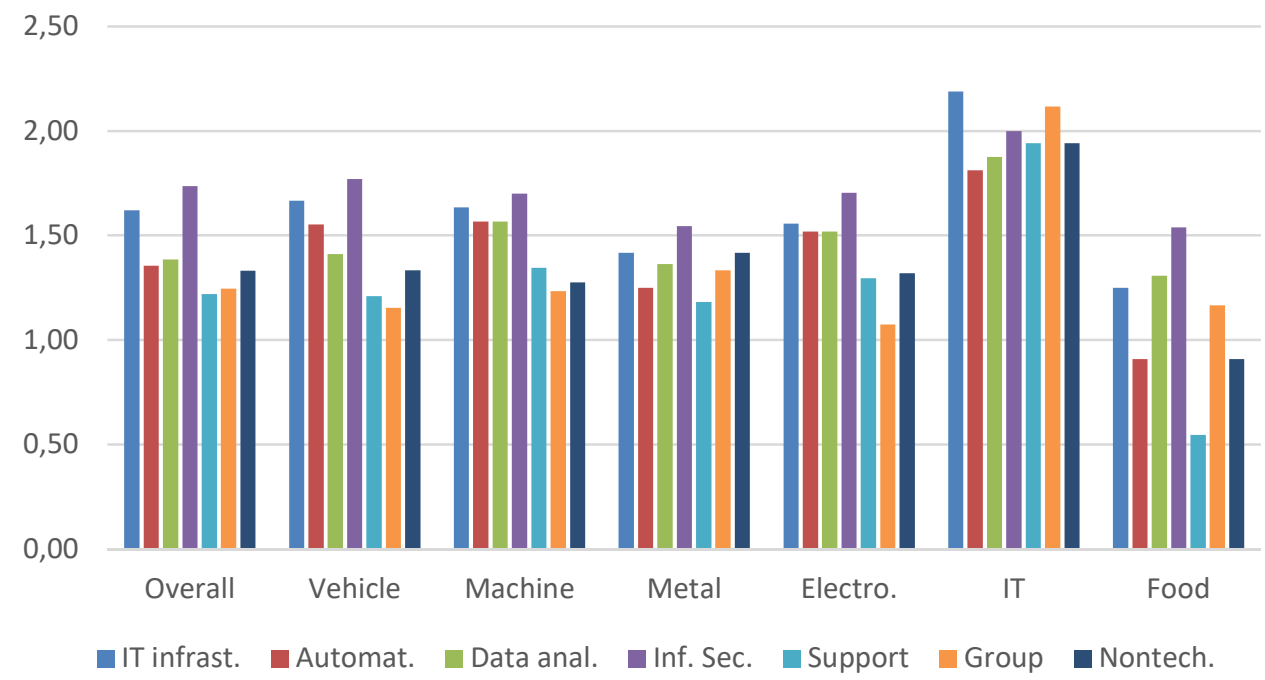


The answers do not correlate significantly with the factors like the size of the company or the ownership. In the case of the most basic competencies in the ICT sector, the values are obviously the highest due to the focused recruitment and the typically intellectually demanding job profiles. Possible responses included the existence and fulfilment of expectations by employers at the same time. The low values in the food industry can be explained rather by the competences that were considered irrelevant in the sector than actual dissatisfaction with employees.

\section{Research \& development services}

Figure 13 Ratio (\%) of companies satisfied with domestic R\&D offering

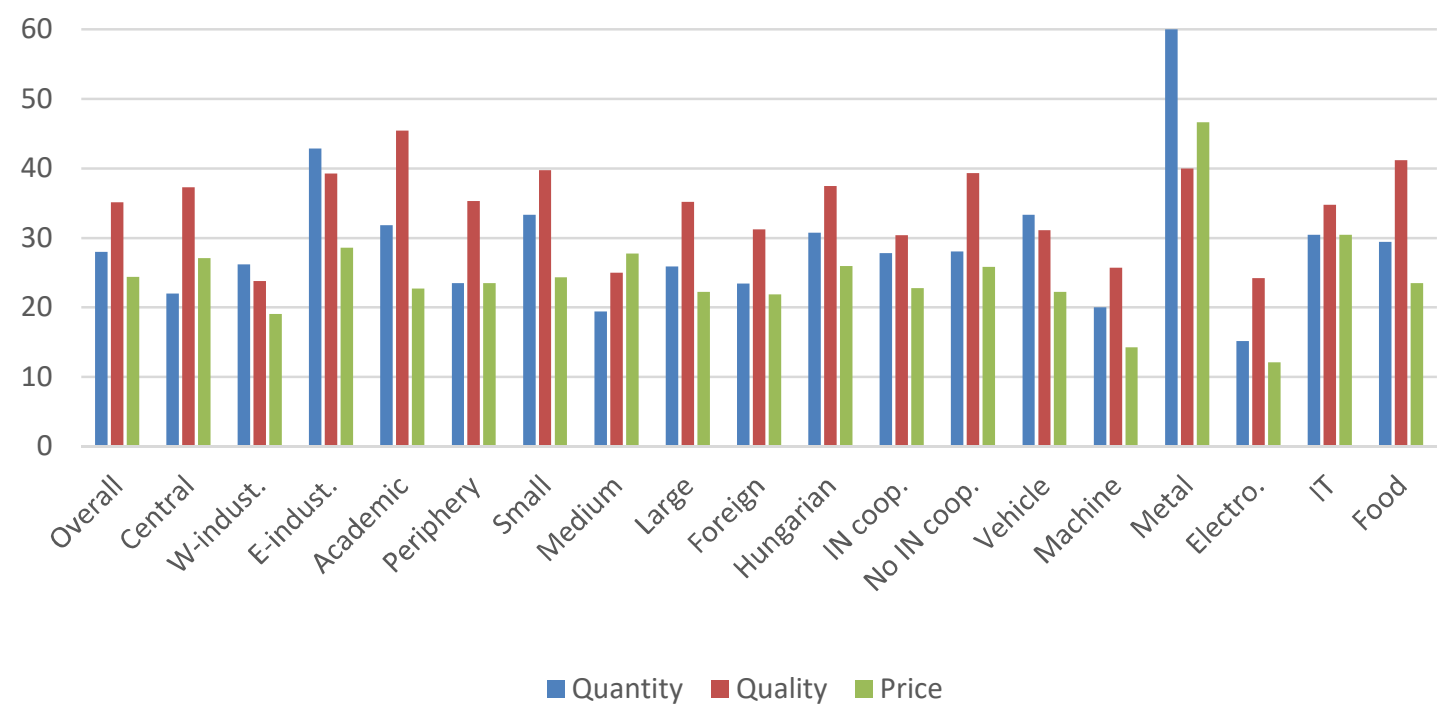

Generally speaking, respondents are not really satisfied with domestic R\&D results and services, which, being less fixed to explicit locations, make it difficult to formulate definite subnational spatial findings (see Figure 13). However, it is striking that the central region, and especially the Western industrialized counties, are more dissatisfied. But one has to be cautious in the interpretation since there might be significant geographical differences in user expectations as well. Smaller companies are somewhat more satisfied with the performance of the R\&D sector, which provides hopefully the evidence that they are making use of the services and also cooperating with the players. The outstanding value of the metal industry is undermined by the fundamental dissatisfaction of the electronics sector, which, regarding the role of the industry, should be taken into account in strategic planning. 
Obstacles

Figure 14 Obstacles of Industry 4.0 per county group

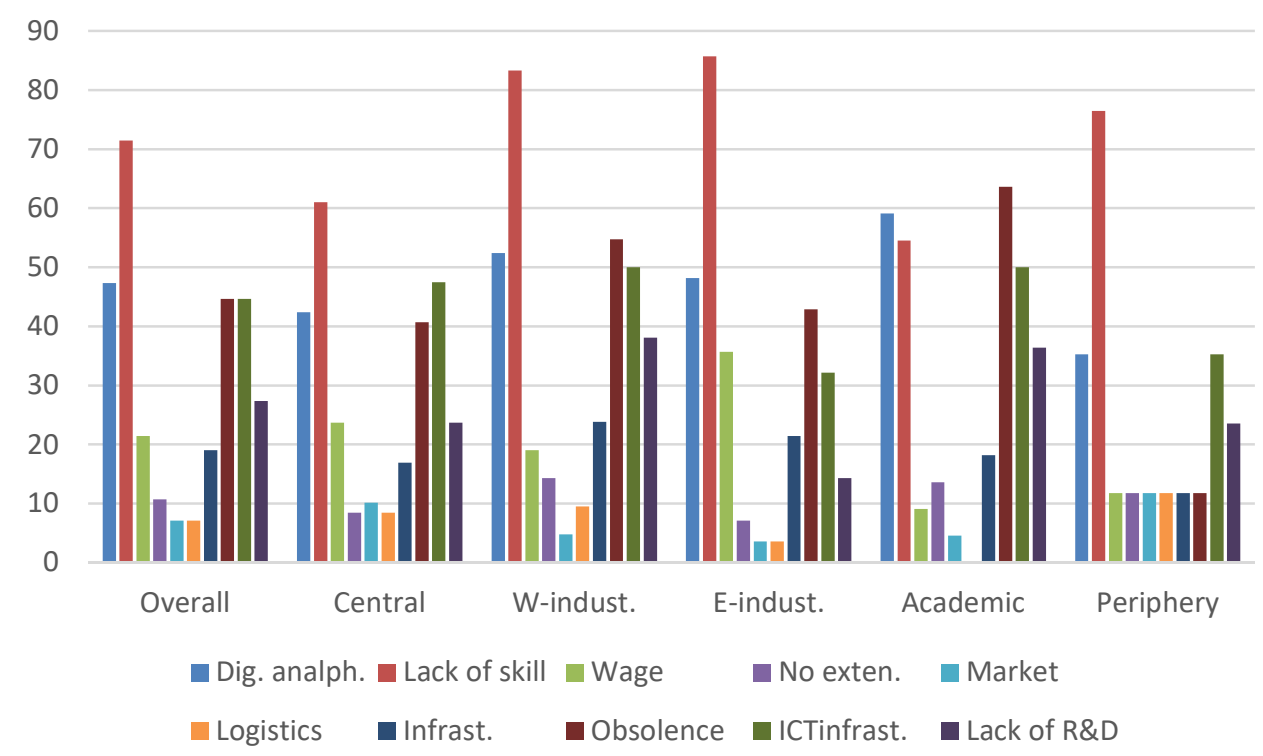

Among the constraints that are limiting competitiveness to increase, the lack of skilled labour is by far the largest problem, which was marked by more than $70 \%$ of the respondents (see Chyba! Nenalezen zdroj odkazů.). In this regard, the central region and the knowledge centre counties don't perceive this as such a grave problem, possibly due to the better training opportunities in large cities and their less industrial profile. Notwithstanding, and at the same time, digital illiteracy is the biggest problem in the counties where the three largest universities are located - but on the industrial periphery, this issue seems to be less problematic. Rising wage costs - presumably due to the effects of extensive industrial development anticipated in the near future - mostly affect companies in the Eastern reindustrializing counties. Neither the lack of expansion opportunities, nor the shrinking market opportunities, nor the rising logistics costs are a major constraint. Although the difference is not significant, it is definitely noteworthy that the underdeveloped infrastructure appears to be the largest problem in the most developed area, while this is rated as the smallest unfavourable factor on the periphery. Obsolete production technologies and processes in peripheral counties are not considered to be an obstacle (this may be due to newer plants), but the opposite is true in knowledge centres. Accessibility of information and communication technologies is an obstacle everywhere. 
Figure 15 Obstacles of Industry 4.0 per sector

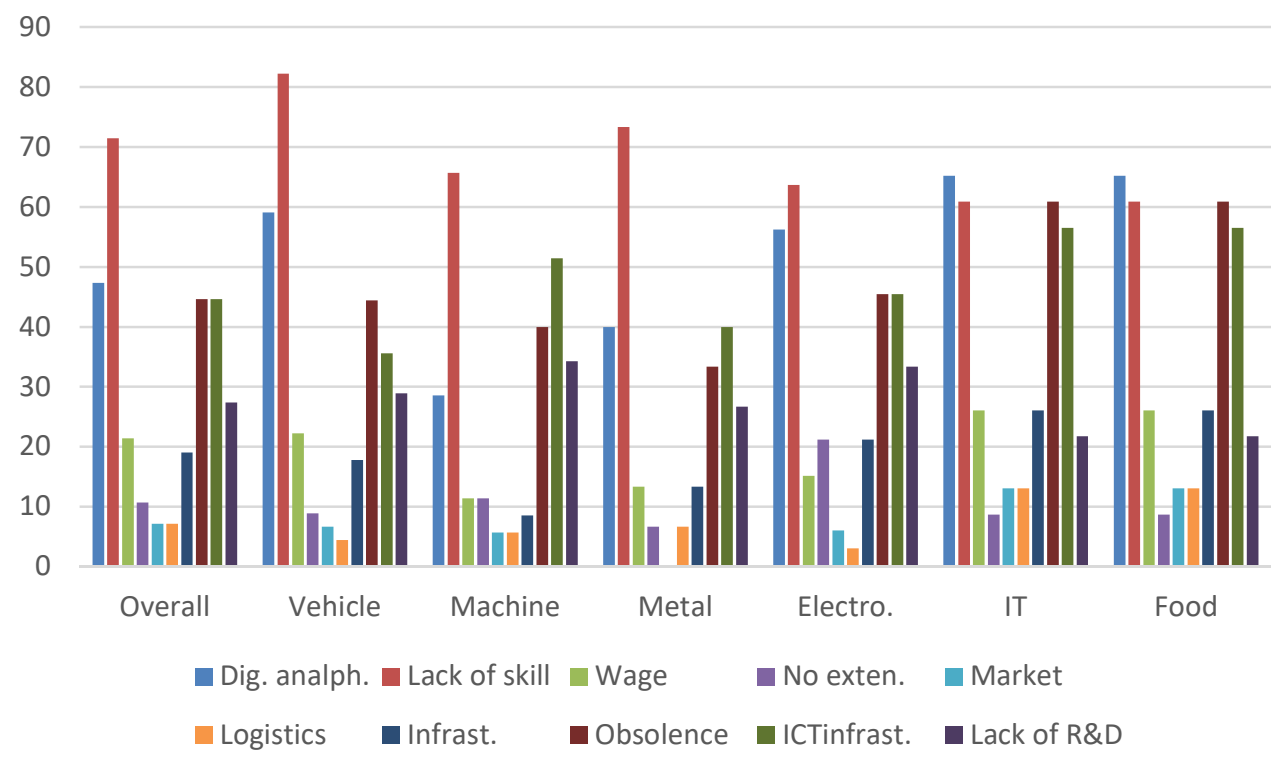

Interestingly, there are no significant differences regarding company size or ownership. Digital illiteracy is not a problem for the machinery industry, but surprisingly, is marked as one of the major problems besides the IT and the food companies (see

Figure 15). The lack of skilled labour is most afflicting the vehicle industry. Obsolete technologies primarily disrupt the food industry and the ICT sector - for the latter, it is most likely a factor limiting market expansion opportunities for its products and services.

\section{CONCLUSION}

It is generally well understood that industry was a fundamental driver of human development in the past two centuries. The three past phases of industrial development had their own influence on the spatial structure of economy and society, e.g. from coal-based heavy industrial areas, through an extreme concentration of resources for uniform mass production in large cities, to the globally organised production systems and value chains, that has culminated in the fierce competition of countries and regions. The expectations are similar in the case of the fourth stage, too. While having a decreasing general weight in the economic structure that has been a phenomenon typical within developed economies, the ever closer connection to the service sector suggests caution when degrading industry. At this point, researchers may only draw attention to potential scenarios based on current tendencies and scientific theories.

The continuously developing and ever more complex technologies, the production and logistic systems equipped with IT tools, the multi-site production generate some ever more 
demanding new tasks for the companies. With the introduction of the IT solutions in an everexpanding circle, the production and logistic processes, the labour organisation and customer service area undergo substantial changes. The access channels used by the customers and their habits diversify and move in the future more towards the services than the products. It will be possible to react quicker to the customer needs together with the economical and efficient mass production of customised products. The industrial production can be integrated into an intelligent environment that is called smart factory in the literature (Kagermann et al., 2013). When preparing for the future, the companies are forced to turn away from traditions both in their operation and acting role if they want to preserve their market position and competitiveness.

The triple helix model in its basic form is rather a tool of creating the innovative spatial economy than that of the governmental sector's specific development policies, although - as a force to generate one of the most efficient forms of cooperation in the innovation system - may bring essential contribution to their performance, too. The more so, as the success of the progress lies in the hands of the human resources, the development of which is of crucial importance. The cooperation between, and the geographical clusterization of the entities of the economic, academic and governmental spheres support the ever more accelerating innovations and then their diffusion, which is the foundation to increase competitiveness and thus is the token of progress (Etzkowitz \& Leydesdorff, 1997; Porter, 1998). According to the best practice, the institutional foundation of the digital transformation of the industry is provided by the platform based model of the industrial ecosystem that determines the new patterns of cooperation between cultures, structures and systems of partnership, together with the management of the entire industrial ecosystem as the fundamental paradigm of Industry 4.0 development policy.

International experiences show that an ecosystem that enables the digital transformation of industry and the optimal harnessing of the synergies induced by the innovations assumes a sensitive and advanced inter-institutional cooperation culture (Roland Berger, 2015). Specifically, the implementation of the interactive institutional models that are to renew the system of the relationship network both in the private and public sectors and to ensure their efficient cooperation may be of immense positive impact.

In Hungary, where the weight of the manufacturing industry exceeds the European average, and specifically, the reinforcement policy of reindustrialization tendencies are embedded deeply in world economy, that affect mainly the vehicle industry and electronics, it is indispensable to formulate adequate and proactive responses to the new challenges of the fourth 
industrial revolution. Industry 4.0 offers the opportunity to break out from the middle-rangeincome trap of semi-peripheral countries, but also incorporates the threat of falling away. Industry plays a prominent role in the regional development of each county, apart from the country's capital city (Lengyel, 2016). Thus, dealing with Industry 4.0 related issues is of utmost importance. In the analysis outlined in the article that was performed on the basis of territorial categories created on a topic-relevant sample by adhering to the logic of industry economics, though no extreme regional differences were encountered, but some observations worth to explore have been made.

The penetration of the innovations is typically promoted on the regional level, too, determined to a great extent by substantial foreign investments and an openness in the external economy. Moreover, it is correlated with the sectoral structure of the industry (see the dominance of machinery industry), too. The peripheral regions perform definitely weaker than those ahead of the others, while there is no evidence of a West-East polarization among the latter, which is partly explicable with structural factors.

The companies' satisfaction with the competencies of their workforce is nowhere good enough and is explicitly low in the periphery. In full conformity with these findings, the most painful obstacles to making progress in Industry 4.0 is digital literacy and the lack of the necessary skill. This defines one direction of how to advance in the future, i.e. that of the training and education. The focus should move from the lexical knowledge-oriented education to the competency developing education. Supporting lifelong learning and teaching the techniques of continuous adaptation are prerequisites for a successful participation in the competition, while the intention to facilitate integration may contribute to the mitigation of the current social and regional differences. With respect to the latter, valuable views are shared in the literature, both abroad and at home. Here, inter alia the publications of István Nahalka and Péter Radó may be referred to. The generally weak results in important aspects like human resources, $\mathrm{R}+\mathrm{D}$ services and the obstacles to cope with, implicitly support the need for the ecosystem-based approach of regional development.

Apart from the emphasis on these differences, the general picture shows optimism about the future implying that, under appropriate circumstances, the companies are open for the changes to come.

\section{SUMMARY}

This paper aims to investigate the role of geographic regions in connection with the economic structure in the processes of the evolving fourth industrial revolution or, from another point of view, the regional effects 
of the above-mentioned in Hungary. For this reason, some important consequences of the relevant economic literature were presented. The space forming forces and structure of the Hungarian industry were considered, explicating its post-socialist, semi-peripheral, dualistic characteristics, then discussed the territorial units used as the basis of the analysis.

After laying the theoretical foundations, the data from a questionnaire filled in by companies affected were examined from different some aspects, to ascertain their suitability and to have benchmarks for the analysis. The sample proved to be diverse according to size, ownership and different industry sectors. Examining relevant answers, one can find that sectoral differences are most well-marked (e.g. food industry usually shows to be far less technological progress- and digitization-oriented than machinery sector), being the most important element of regional dissimilarities, too. The biggest gap was between the least industrialized peripheral counties and the others possessing the highest quality of human resources. However, companies are dissatisfied with the competences of the labour force all over the country, which is one of the key issues to be tackled by the government policy. Additionally, evidences of externally driven innovation and a great discrepancy between completed and expected technological advancement were found, showing the contrast between the facts of how companies see the potential in Industry 4.0, and how they realise their compelling task of achieving still a lot to catch up.

\section{Acknowledgement}

This research has been supported by the „Felsőoktatási Intézményi Kiválósági Program - Digitális ipari technológiák kutatása a Széchenyi István Egyetemen" project (20523-3/2018/FEKUTSTRAT) and the National Research, Development and Innovation Office - NKFIH \#115577 contract (,A hazai középvállalati szektor szerepe az ipar területi versenyképességében") grants of Hungary.

\section{REFERENCES}

Barta, G. (2002). A magyar ipar területi folyamatai 1945-2000. Dialóg-Campus, BudapestPécs

Barta, G., Czirfusz, M., \& Kukely G. (2008). Újraiparosodás a nagyvilágban és Magyarországon. Tér és Társadalom, 22(4), 1-20.

Bharadwaj, A., El Sawy, A., Pavlou, P. A., \& Venkatraman, N. (2013). Digital business strategy:toward a next generation of insights. MIS Quarterly, 37(2), 471-482.

CEC (1996). First Report on Economic and Social Cohesion. EC, Brussels

Chikán, A. (2008). Vállalatgazdaságtan. AULA Kiadó, Budapest.

Cristopherson, S., Martin, R., Sunley, P., \& Tyler, P. (2014). Reindustrialising regions: rebuilding the manufacturing economy. Cambridge journal of regions, economy and society, vol. 7. no. 3., 351-358.

Cséfalvay, Z. (2004). Globalizáció 1.0, 2.0. Nemzeti Tankönykiadó, Budapest

Cséfalvay, Z., \& Nikodémus, A. (1991). Két századvég Magyarországon. Gyorsjelentés a gazdaság regionális átrendeződéséről. Tér és Társadalom, 5(4), 69-89.

EIS (2016). European Innovation Scoreboard. European Union http://ec.europa.eu/growth/ industry/innovation/facts-figures/scoreboards_hu, Downloaded: 2017.03.12.

Enyedi, G. (2012). Városi világ. Akadémiai kiadó, Budapest

Erol, S., Schumacher, A., \& Sihn, W. (2016). Auf dem Weg zur Industrie 4.0 - ein dreistufiges Vorgehensmodell. In: Biedermann, H. (szerk.). Industrial Engineering und Management. Springer Gabler, 247-266.

Etzkowitz, H., \& Leydesdorff, L. (1997). Universities and Global Knowledge Economy. A Triple Helix of University - Industry - Goverment Relations. Printer, London

Faragó, L., \& Lux, G. (2014). Kurrens portéka vagy múzeumi tárgy? Növekedési pólusok és iparági körzetek a fejlesztéspolitikában. Tér és Társadalom, 28(2), 11-30.

Horváth, G. (2000). Magyarország területi szerkezete és folyamatai az ezredfordulón. MTA RKK, Budapest

Kagermann, H., Wahlster, W., \& Helbring, J. (2013). Securing the Future of German Manufacturing Industry: Recommendations for Implementing the Strategic Initiative 
Industrie 4.0. Final report of the Industrie 4.0 Working Group. Forschungsunion im Stifterverband für die Deutsche Wirtschaft e.V., Berlin

Kiss, É. (2008). A magyar ipar térbeli szerkezetének átrendeződése 1989 után: 2. Területi Statisztika, 11.évf. 5.sz, 544-553.

Kiss, É. (2013). Sokszínü ipari parkállomány. In: Kiss Éva (szerk). A hazai ipari parkok különbözö dimenzióban. Dialóg Campus, Budapest-Pécs, 11-39.

Kiss, J. (2013). A vállalatok szerepe a magyar innovációs rendszerben. In: Inzelt, A.; Bajmócy, Z. (2013) (szerk.). Innovációs rendszerek. Szereplök, kapcsolatok és intézmények. JATEPress, Szeged

Kovács, S., Lux, G., \& Páger, B. (2017). A középvállalatok szerepe a feldolgozóiparban: egy magyarországi kutatás első eredményei. Területi Statisztika 57.évf. 1.sz., 52-75.

KSH [Központi Statisztikai Hivatal] (2017). Magyar statisztikai évkönyv. Budapest

Laseur, L. (2019). The Influence of Industry 4.0 on Reshoring. University of Twente, Netherlands.

Lengyel, I. (2010). Regionális gazdaságfejlesztés. Versenyképesség, klaszterek és alulról szervezödö́ stratégiák. Akadémiai Kiadó, Budapest

Lengyel, I. (2016). A megyék versenyképességének néhány összefüggése a megújult piramismodell alapján. In: Lengyel, I., Nagy, B. (szerk.). Térségek versenyképessége, intelligens szakosodása és újraiparosodása. JATEPress, Szeged

Lux, G. (2017). Újraiparosodás Közép-Európában. Dialóg Campus Kiadó, Budapest

McKinsey \& Company (2013). How to make a city great. Downloaded: 2015.08.12. http://www.mckinsey.com/insights/urbanization/how_to_make_a_city_great

Molnár, E., \& Lengyel, I. M. (2015) Újraiparosodás és útfüggőség. Tér és társadalom, 29:4, 42-59.

Molnár, E. (2017). Globális értékláncok és térbeli gazdasági egyenlőtlenségek: Miről mesél a textil-és ruházati ipar változó földrajza. Földrajzi Közlemények, 141:3, 216-225.

Monostori, L., Kádár, B., Bauernhansl, T., Kondoh, T., Kumara, S., Reinhart, G., ...Ueda, K. (2016). Cyber-physical systems in manufacturing. CIRP Annals - Manufacturing Technology, 65(2), 621-641.

Nick, G, Fülep, I., \& Várgedő, T. (2018). Zászlón a digitalizáció - Ipar 4.0. Új közigazgatás, 11(2), 46-56.

Nick, G., Szaller, Á., Bergmann, J., \& Várgedő, T. (2019) Industry 4.0 readiness in Hungary: model, and the first results in connection to data application. IFAC PapersOnLine. 9th IFAC Conference MIM on Manufacturingm Modeling, Management and Control (Berlin, 28-30, 2019)

NTP [Ipar 4.0 Nemzeti Technológiai Platform] (2017). Az Ipar 4.0 fogalma. https://www.i40platform.hu/sites/Industrie\%204.0_Definition.pdf ， Downloaded: 2017.10.12.

OECD (1997). Regional Competitiveness and Skills. Paris

OECD (1998). The Competitiveness of Transition Economies. Paris

Pongrácz F., \& Nick G. (2017). Innováció- a fenntartható növekedés kulcsa Magyarországon. Közgazdasági Szemle, LXIV.évf. július - augusztus, 723-737.

Porter, M. E. (1990). The Competitive Advantage of Nations. The Free Press, N.Y.

Porter, M. E. (1998). The Adam Smith Address: Location, Clusters, and the "New" Microeconomics of Competition. Business Economics, 33(1), 7-13.

Porter, M., \& Heppelmann, J. (2014). How Smart, Connected Products Are Transforming Competition. Harvard Business Review 2014 nov. (https://hbr.org/2014/11/how-smartconnected-products-are-transforming-competition)

Rechnitzer, J. (1998). A területi stratégiák. Dialóg Campus Kiadó, Budapest-Pécs

Rechnitzer, J., \& Smahó, M. (2011). Területi politika. Akadémiai Kiadó, Budapest 
Roland Berger (2015). Industry 4.0 - The digital transformation of industry. Munich

Roland Berger (2016a). Industry 4.0 - Challenge for the $F \& B$ industry in Greece, advantage or competitive disadvantage? Thessaloniki

Roland Berger (2016b). The Industrie 4.0 Transition Quantified. Think Act, April 2016, Munich

Schuh, G., Anderl, R., Gausemeier, J., Hompel, M., \& Whalster, W. (2017). Industrie 4.0 Maturity Index. Herbert Utz Verlag, München

Spath, D., Ganschar, O., Gerlach, S., Hämmerle, M., Krause, T., \& Schlund, S. (2013). Produktionsarbeit der Zukunft Industrie4.0. Fraunhofer Verlag, Stuttgart

Szalavetz, A. (2015). Szakosodás és feljebb lépés a multinacionális vállalatok globális értékláncain belül. http://real-d.mtak.hu/861/7/dc_102715 doktori_mu.pdf, Downloaded: 2017.12.12.

Szalavetz, A. (2016a). Az ipar 4.0 technológiák gazdasági hatásai: egy induló kutatás kérdései. Külgazdaság, 60.évf. 7-8.sz., 27-50.

Szalavetz, A. (2016b). Egy elöre bejelentett forradalom krónikája Magyarországon: ipar 4.0technológiák és a hazai feldolgozóipari leányvállalatok. Külgazdaság, 60.évf. 9-10.sz., 28-48.

Szerb, L. (2010). A magyar mikro-, kis és középvállalatok versenyképességének mérése és vizsgálata. Vezetéstudomány, 41(12), 20-35.

United Nations (2011). Population distribution, urbanization, internal migration and development: An international perspective. New York, Downloaded: 2017.03.12.

United Nations (2015). Department of Economic and Social Affairs, Population Division 2015 forecast. https://esa.un.org/unpd/wpp/, Downloaded: 2017.03.12. 